\title{
RECENT DEVELOPMENTS IN THE UTILIZATION OF SAWMILL WASTE IN THE SOUTHERN COAST REGION OF BRITISH COLUMBIA
}

\author{
By J. H. Jenkins, B.A. Sc. \\ Chief, Timber Products Division, Vancouver Laboratory, Forest Products \\ Laboratories of Canada, Forest Service, Department of the Intcrior
}

$\mathrm{T}$ HERE has been a marked improvement in the utilization of mill-waste by sawmills in the Southern Coast region of British Columbia. This waste material, which results from the conversion of the sawlog into lumber, comprises slabwood, trimmings and sawdust. Studies made by the Forest Products Laboratories of Canada, Forest Service, Department of the Interior show that most of this mill-waste is now utilized in some form, especially at mills accessible by truck, rail or scow to large wood-using centres.

The principal forms of waste utilization in this region are as Lath and Shingle Bands, Broom Handles, Pulpwood, Firewood, Sawdust Fuel, and Hogged Fuel. These are discussed in detail in the following paragraphs:-

\section{LATH AND SHINGLE BANDS:}

In the manufacture of lath and shingle bands, selected straight-grain slabwood and trims, 4 feet in length and 1 inch or more in thickness, are used. The amount of mill-waste converted into lath and shingle bands depends largely upon the demand for these two products. When the market for lath and shingle bands is poor, the mill-waste suitable for their manufacture is converted into firewood, and vice versa.

For mills having a profitable market for their mill-waste as firewood, the question frequently arises as to whether it is more profitable to operate the lath-mill or to convert the waste suitable for lath into firewood. Studies made at Coast sawmills by the Vancouver Laboratory show that the same amount ( 60 cubic feet, exclusive or bark) of mill-waste is contained in a cord of firewood (slabs) as is required to produce 1000 pieces of lath. On this basis, if the relative net return from these two commodities is known, it is easy to determine if the mill-waste is being utilized to best advantage.

\section{BROOM HANDLES:}

The manufacture of broom handles from selected sawmill waste is an interesting development during recent years. At present there are two plants 
manufacturing finished broom and hoe handles in British Columbia. These handles, which are exported in considerable volume to the United Kingdom and other world markets, are made from $1 \frac{1}{4}$-inch squares, 48 inches long, for broom handles, and from 60 to 72 inches long for hoe handles. These squares are cut from selected mill-waste of a quality similar to that used for the best grade of lath, special attention being paid to straightness of grain. At the broom-handle factory, these squares are turned on a lathe roughly to shape and size. They are then kiln-dried to a moisture content of around 10 per cent prior to manufacture into the finished article.

\section{PULPWOOD:}

The development of the pulp and paper industry on the Pacific Coast during recent years has furnished an outlet for selected mill-waste as pulpwood. Unfortunately, however, from the standpoint of utilizing all mill-waste for this purpose, a large proportion of the waste produced in British Columbia is composed of Douglas fir, Western red cedar, and other species with low pulping properties under present commercial practice. A considerable portion of the slabs, edgings, and trimmings produced as "waste" at sawmills cutting Western hemlock, "true fir" (Abies), and spruce (Sitka and Engelmann), is, however, of a form and character suitable for use as pulpwood.

The hemlock and spruce mill-waste may be sold either in the form of clean barked slabwood or as pulp chips. The British Columbia pulpmills are not at present utilizing any mill-waste for pulpwood. The hemlock and spruce sawmills in British Columbia are therefore dependent upon the pulpmills in Washington for their market for sawmill waste. At six sawmills in the Southern Coast region, selected hemlock and spruce mill-waste is removed from the waste conveyor, barked, and either shipped as pulpwood or converted into pulp chips at the sawmill. The pulpwood and chips are then transported by rail or water to pulp-mills in Washington.

When the mill-waste is sold unchipped as pulpwood, the basis of measurement is the cord, but where the waste is chipped at the sawmill, the basis of measurement is the unit ( 200 cubic feet).

In studies made by the Vancouver Laboratory at representative hemlock sawmills in British Columbia, it was found that a much higher percentage of mill-waste was utilized when it was converted into pulp chips at the mill than when the waste was sold as pulpwood. For mills having a chipping plant at the waste conveyor, 62.6 per cent of the hemlock mill-waste was utilized, while at those mills shipping the barked pulpwood (unchipped), only 36.3 per cent of the total mill-waste was utilized. 
The cost of sorting, barking, and chipping mill-waste is comparatively high, and unless the work is efficiently handled and carefully supervised, the margin of profit for the sawmill is low. An increased demand for hemlock and spruce logs for lumber, with a resultant rise in price, would automatically increase the possibilities of salvaging mill-waste for pulpwood.

\section{FIREWOOD AND SAWDUST:}

The mill-waste not utilized for the manufacture of lath, broom handles, or pulpwood, may either be cut into lengths for sale as firewood or manufactured into hogged fuel. At Douglas fir sawmills in British Columbia, having a well organized firewood department, the mill-waste is selected from the waste conveyor, trimmed to 16-inch lengths, and then sorted into various classes of firewood. The main firewood classes are Slabs, Edgings, and Inside Fir (square-edged Trims) from the sawmill, and Kindling, from the planing mill.

Where the market for firewood is poor or the demand for hogged fuel is good, the mill-waste may be fed to a fuel-hog to produce hogged fuel. Hogged fuel, as produced by the ordinary type of sawmill hog, is used for fuel in sawmills, pulp-mills, electric power plants, and other industrial plants where it can be fed into the furnace by a chute. Special machines are necessary for the conversion of mill-waste into fuel sufficiently fine for use in sawdust-burners equipped with fuel hoppers.

Sawdust and shavings are used by the sawmills for their own power development. This fuel is carried by conveyors to fuel bunkers from which it is fed by gravity into the furnace through openings in the arch, where it burns in cone-shaped piles. The amount of fuel required by the individual sawmill varies with the season of the year, the efficiency of the power plant, and the steam requirements of the dry kilns. As a rule, however, the amount of sawdust produced is more than adequate to operate the sawmill power plant, and a large surplus remains. The increasing use of sawdust for heating dwellings, apartment houses, and theatres, now absorbs a large part of this surplus.

The demand for sawdust for house heating has provided suitably located mills with a market for their surplus sawdust, which would otherwise be a waste product. The sale and distribution of sawdust has now become a well organized business on the Pacific Coast. The sawdust is usually handled by independent fuel companies, who purchase it from the sawmill at the fuel bunkers. It is delivered either in bulk or in sacks. Delivery in bulk is only possible where the storage space is accessible to a roadway. When it is delivered. in sacks, the price quoted (which is higher than for bulk) includes the placing of the sawdust in the house basement. 
Studies made by the Forest Products Laboratories show that:-

(a) The storage of green sawdust under cover for periods up to two years is entirely feasible, the moisture content and burning qualities being satisfactory at the end of the storage period.

(b) The storage of sawdust in the open, unprotected from rain, is not satisfactory, as the moisture content of the sawdust rapidly increases to a sufficient extent to interfere with proper combustion.

(c) No trouble from "heating" or staining is experienced in the storage of Douglas fir sawdust in house basements.

Many of the fuel companies now accumulate and store large quantities of sawdust during the summer months to assist in meeting any winter shortage. In addition, the retail price of sawdust is reduced during the summer, and, as a result, a very appreciable volume of sawdust is placed in storage in house basements in the summer. The sale of sawdust is therefore now well distributed throughout the year and the mills are assured of a steady market for their surplus. In fact, the demand for sawdust for domestic heating is so great that the future may see the installation of special machinery for the conversion into sawdust of the poorer quality of mill-waste now used for firewood. The market for sawdist for house heating is apparently limited only by the supplies available (which are determined by the quantity of lumber sawn), while it is becoming increasingly difficult to market as firewood certain forms of mill-waste, such as green edgings. The fuel situation would therefore be benefitted by the development of satisfactory means of converting surplus mill-waste into sawdust suitable for use in sawdust burners.

\section{POTENTIAL USES FOR MILL-WASTE:}

In a previous portion of this article, the present methods of utilizing sawmill waste in British Columbia have been briefly discussed. ${ }^{1}$ There are, in addition, other potential uses for mill-waste, some of which are impracticable under present economic conditions, while others have not been developed on account of lack of knowledge or lack of contact with suitable markets. The more promising of these potential uses for mill-waste in British Columbia are briefly described in the section following:-

\section{(a) Briquetting:}

The compression of sawdust and other forms of wood-waste into briquettes for fuel purposes has been successfully carried out in Europe for a

\footnotetext{
1 For detailed information in this connection, see Forest Service Bulletin 83 "Snwmill Waste and its Utilization in British Columbia." and numerous reports avalable on request to the Forest Products Lahoritories of Canadi.
} 
number of years, but has met with little success in Canada. The requisites for success in briquetting mill-waste are (1) a large and continuous supply of suitable raw materials, (2) low production costs, and (3) a ready sale for the finished product at fair prices. As a general rule, the briquettes must be marketed in the immediate region of production.

There are a number of briquetting systems in use in Europe, some using a coal-tar pitch or other binding material, others depending upon a combination of high temperature with the pressure maintained during processing. In the latter case, the resinous materials in the wood serve as a natural binder. The continuous drying of large quantities of wood-waste, necessary in the manufacture of briquettes, is a difficult and often expensive problem.

A process originally developed for the manufacture of briquettes fronr Western white pine shavings is now in successful operation in a number of lumber producing districts in Washington and Oregon for the utilization of dry Douglas fir and pine waste material. Shavings and sawdust are ground fine in a hammer mill and processed by heat and pressure. The resultant briquettes, which are cylindrical in shape, four inches in diameter, twelve and one-half inches long, and weighing about eight pounds, have been used with: success in furnace, cook-stove, and fireplace.

\section{(b) Wood distillation:}

The main features of the destructive distillation process for softwoods: are briefly as follows: the wood is placed in an air-tight oven, which is heated by externally applied heat, and the resulting gaseous products are conducted: from the oven and cooled. A portion of the gases thereupon condense into: liquids of both an oily and a watery nature. The residue left in the oven is charcoal. The oily distillates yield wood turpentine, pine oil, tar oil, and heavy tar. The acid water contains wood alcohol, acetone, and acetic acid, but on account of the small yield of these by-products in resinous wood distillation: they are ordinarily discarded.

The yields obtained in experiments with unselected Douglas fir wood are considerably lower than those obtained in commercial practice from pine in the Southern United States. While the yields of alcohol and acetate of lime from Douglas fir are practically the same as from the Southern pine, they are so small in both cases as to make their recovery unprofitable at present. The combined yield of turpentine and other oils from unselected Douglas fir is less than one-fourth of that from Southern pine, but it is possible to select resinous portions of Douglas fir which will approximate the yields obtained from Southern pine.

Wood distillation, with the exception of small plants in British Columbia and Washington producing charcoal without recovery of by-products, is not 
USE OF SAWMILL WASTE

now practiced on a commercial scale on the Pacific Coast. Experiments with a number of new processes for the destructive distillation of wood-waste have been made, in the past, in British Columbia, but none of them have produced on a commercial scale: The principal problem in the destructive distillation of softwood mill-waste in British Columbia appears to be the profitable disposal of the products of distillation. The prices received for pine oil and turpentine depend on the prices ruling for the products obtained from gum, which are superior in quality to those produced by destructive distillation.

As a general rule, the success of a distillation plant in British Columbia will depend on the assurance of a good local market for the resultant products, especially charcoal. While there has been considerable development in the manufacture of charcoal in British Columbia during the past year, the demand is, at present, confined to charcoal made from hardwoods, alder being the principal wood used locally.

\section{(c) Producer-gas plants:}

Wood-gas has been used for a number of years in Europe as a substitute for gasolene and fuel oil in automobile and stationary engines. This form of wood utilization appears to have great possibilities in British Columbia as a source of power for trucks, logging and mining equipment, especially in isolated districts where gasolene and fuel oil are expensive.

The wood-gas is generated in a portable plant, which is installed on the running board of a truck, or beside a stationary engine. Charcoal is used to generate the wood-gas, which gives very satisfactory and economical performance as fuel in all types of gasolene engines. A producer-gas equipped truck in Vancouver is reported to have run 120 miles with an average gross load of $21 / 2$ tons on 84 pounds of alder charcoal, costing 76 cents.

For the satisfactory use of producer-gas equipped trucks and plants, a dependable supply of suitable charcoal is necessary. This charcoal supply could either be obtained from simple portable kilns operated by the individual plant owner or by the establishment of larger plants at different distributing centres throughout the Province. In this later case, where a definite market for the charcoal is assured, a simple form of distillation for the recovery of the woodtars might prove profitable, especially if they are found satisfactory for road surfacing. The Forest Products Laboratories of the Department of the Interior, are now making a series of tests to determine the relative efficiencies of Douglas fir, spruce, lodgepole pine, poplar, and alder charcoal for use in producer-gas plants. These different species were selected for testing as representing the woods that would be most accessible for charcoal manufacture in different parts of British Columbia. 
No attempt has been made in this article to deal with all the potential methods of utilizing the sawmill waste of British Columbia. Many of these methods are not profitable at the present time, either on account of lack of accessible markets or because certain steps in the technical process of the waste utilization require additional research. This article has endeavoured, however, to show that some form of mill-waste utilization is being practised to a very appreciable extent in British Columbia. While the resultant products. of most of this utilization are of comparatively low value, being sold as fuel or pulpwood, yet the quantities handled are so large that the Southern Coast mills derive an appreciable net revenue from their present methods of waste disposal. This means that mill-waste now has a positive monetary value, which is a factor that will have to receive consideration in developing new and improved methods of waste utilization.

\section{THE SCOTTISH FORESTRY JOURNAL Mr. Johannes Rafn}

A seedsman of world-wide reputation has recently passed away in the person of Mr. Johannes Rafn, Copenhagen, who died on 11 th July last at the age of 81 .

After being trained as a gardener, Mr. Rafn went abroad to take classes in several countries, and was in England in 1877. On his return to Denmark he started a "Plant School" which ran for a few years until the destruction of the crop in two successive years by cockchafers brought the venture to an end. Although this appeared to be a great calamity at the time, $\mathrm{Mr}$. Rafn afterwards considered it as a most fortunate occurrence, for it led him to found his now world-famous "Skovfrokontoret" or Forest Seed Establishment in Hellerup in 1887. After ten years it was removed to Frederiksberg, and later to Copenhagen.

The name of Mr. Johannes Rafn will always be held in high honour in Denmark and elsewhere by reason of the great work he accomplished in building up a great tree seed distributing centre from which many exotic species were introduced, and it was fitting that his work should have received State approval on his seventieth birthday when he was made a "Ridder af Dannebrog." 